\title{
Islet Amyloid Polypeptide (Amylin) Is Expressed in Sensory Neurons
}

\author{
Hindrik Mulder, ${ }^{1}$ Arnold Leckström, ${ }^{2}$ Rolf Uddman, ${ }^{3}$ Eva Ekblad, ${ }^{1}$ Per Westermark, ${ }^{2}$ and Frank Sundler ${ }^{1}$ \\ ${ }^{1}$ Department of Medical Cell Research, University of Lund, '2Department of Pathology, University Hospital, \\ Linköping, and ${ }^{3}$ Department of Otolaryngology at Malmö General Hospital, University of Lund, Sweden
}

Islet amyloid polypeptide (IAPP) or amylin is a hormone candidate predominantly expressed in insulin cells. A role for IAPP in the regulation of glucose homeostasis and the development of non-insulin-dependent diabetes mellitus has been proposed. IAPP is structurally related to the sensory neuropeptide calcitonin gene-related peptide. In the present study, using in situ hybridization, immunocytochemistry, and immunochemistry, the expression of IAPP in sensory neurons in the rat was investigated. IAPP was expressed in a population of small- to medium-slzed nerve cell bodies in dorsal root ganglia from all levels and in the jugular-nodose and trigeminal ganglion; IAPP-expressing nerve cell bodies constituted a subpopulation of those expressing calcitonin gene-related peptide. In addition, IAPP. like immunoreactivity occurred in nerve cell bodies storing substance $P$ and pituitary adenylate cyclase-activating polypeptide. IAPP-immunoreactive nerve fibers were encountered in the dorsal horns of the spinal cord, and to a lesser extent in peripheral tissues receiving sensory innervation; IAPP-immunoreactive fibers constituted a subpopulation of those containing calcitonin gene-related peptide and/or substance $P$. The immunochemical determinations demonstrated a low level of IAPP-like immunoreactivity in the dorsal root ganglia and spinal cord, which chromatographically coeluted with authentic rat IAPP. We conclude that IAPP is expressed in sensory neurons, thus being a novel sensory neuropeptide candidate for which a physiological role remains to be identified.

[Key words: islet amyloid polypeptide, amylin, calcitonin gene-related peptide, neuropeptides, sensory nervous system, in situ hybridization, immunocytochemistry, radioimmunoassay (RIA)]

Islet amyloid polypeptide (IAPP), also designated amylin, is the main constituent of anyloid formed in insulinomas or in islets from patients with non-insulin-dependent diabetes mellitus (Westermark et al., 1986; Cooper et al., 1987). The peptide is

\footnotetext{
Received Apr. 17, 1995; revised July 21, 1995; accepted July 25, 1995.

This study was supported by the Swedish Medical Research Council (Project 12X-4499 and 5941). The Swedish Diabetes Association, The Heart Lung, Albcrt Påhlsson, Wibcrg and Crafoord Foundations, The Novo Nordisk Insulin Fund and the Faculties of Medicine, University of Lund and University of Linköping. We gratefully thank Dr. Amy Percy, Mr. Mark Fineman, and Dr. Joy Koda (Amylin Pharmaceuticals Inc., San Diego, CA) for providing F 05524 and data on antibody characterization.

Correspondence should be addressed to Hindrik Mulder, M.D., Department of Medical Cell Research, University of Lund. Biskopsgatan 5, S-22362 Lund, Sweden.

Copyright (C) 1995 Society for Neuroscience $\quad 0270-6474 / 95 / 157625-08 \$ 05.00 / 0$
}

predominantly expressed in insulin cells (Johnson et al., 1988), where it is stored in the same secretory granules as insulin (Lukinius et al., 1989). The physiological role of IAPP has not yet been resolved. However, the data available suggest a role for IAPP in glucose homenstasis: IAPP constrains insulin-mediated glycogenesis in skeletal muscle (Leighton and Cooper, 1988; Frontoni et al., 1991) and inhibits insulin secretion (Wang et al., 1993; Fürnsinn et al., 1994).

IAPP bears an approximately $50 \%$ structural homology with calcitonin gene-related peptide (CGRP) (Westermark et al., 1986; Cooper et al., 1987), which is widely expressed in the CNS and PNS, the sensory nervous system in particular (Sundler et al., 1985; Ishida-Yamamoto and Tohyama, 1989). The genes for IAPP and CGRP are located on chromosomes 12 and 11, respectively, and are probably the result of a duplication of an ancestral gene (Höppener et al., 1984; Nishi et al., 1989). Against this background, it is tempting to speculate that IAPP is also expressed in the nervous system. In fact, IAPP mRNA has been demonstratcd in extracts from rat dorsal root ganglia (Ferrier et al., 1989; Nicholl et al., 1992) and, recently, it was shown that in the chicken IAPP is predominantly expressed in the brain (Fan et al., 1994). However, the cellular expression and distribution of IAPP in the sensory nervous system are not known. Therefore, by use of in situ hybridization, immunocytochemistry, and immunochemistry, we have investigated the expression of IAPP in sensory ganglia and its occurrence in the spinal cord and neuronal elements of peripheral tissues in the rat.

\section{Materials and Methods}

Tissue. Adult female Sprague-Dawley rats $(n=10)$ were used; they were anesthetized by pentobarbitone and killed by exsanguination. Dorsal root ganglia from the levels $\mathrm{C}_{1}$ to $\mathrm{L}_{6}$, jugular-nodose, and trigeminal ganglia were rapidly dissected. The following tissues were investigated for the possible occurrence of IAPP-containing nerve fibers: nose skin, tongue, foot pad, airways, oesophágus, gastrointestinal tract, pancreas, urinary bladder, uterus, and spinal cord (cervical, thoracic, and lumbar levels). In addition, dorsal root ganglia and spinal cord from newborn rats (day $0 ; n=5$ ) were excised. For in situ hybridization, the specimens were frozen on dry ice and stored at $-80^{\circ} \mathrm{C}$; for immunocytochemistry, the specimens were immersed overnight in $2 \%$ paraformaldehyde and $0.2 \%$ picric acid (buffered in $0.1 \mathrm{M}$ phosphate, $\mathrm{pH} 7.2$ ) followed by repeated rinsing in sucrose-enriched $(10 \%)$ buffer. The specimens were frozen on dry ice and stored at $-80^{\circ} \mathrm{C}$ until being cut on a cryostat $(10 \mu \mathrm{m})$. For immunochemistry (radioimmunoassay, RIA) and reverse phase high-performance liquid chromatography (HPLC) pooled $(n=10)$ dorsal root ganglia and specimens from the spinal cord were frozen on dry ice.

In situ hybridization. Two 30-mer oligodeoxyribonucleotide probes complementary to nucleotides 80-109 and 215-244 in cDNA encoding rat IAPP were used (Leffert et al., 1989). These sequences were unique 


\begin{tabular}{|c|c|c|c|c|}
\hline Code & Antigen & Raised in & Dilution & Source \\
\hline F 055-24 & Human IAPP $1-10$ & Monoclonal & $1: 320$ & $\begin{array}{l}\text { Amylin Pharmaceuticals Inc., } \\
\text { San Diego, CA }\end{array}$ \\
\hline 8425 & Rat $\alpha$-CGRP & Rabbit & $1: 640$ & $\begin{array}{l}\text { Euro-Diagnostica, Malmö, } \\
\text { Sweden }\end{array}$ \\
\hline SP 7 & Substance $P$ & Rabbit & $1: 160$ & $\begin{array}{l}\text { Dr. P. Emson, MRC Gruop, } \\
\text { Cambridge, UK }\end{array}$ \\
\hline 9223 & Nitric oxide synthase & Rabbit & $1: 1280$ & Euro-Diagnostica \\
\hline $88121-3$ & PACAP 1-27 & Rabbit & $1: 640$ & $\begin{array}{l}\text { Dr. A. Arimura, Tulane } \\
\text { University School of } \\
\text { Medicine, New Orleans, } \\
\text { LA }\end{array}$ \\
\hline N-SOM & Somatostatin & Rabbit & $1: 800$ & $\begin{array}{l}\text { Inc. Star Corp., Stillwater, } \\
\text { MN }\end{array}$ \\
\hline 8416 & Porcine galanin & Rabbit & $1: 320$ & Euro-Diagnostica \\
\hline
\end{tabular}

for rat IAPP mRNA (GenBank EMBL, 12/94). Also, a 30-mer oligoprobe complementary to nucleotides $3839-3868$ in rat $\alpha$-CGRP cDNA was used (Amara et al., 1984). The probes were $3^{\prime}$-endtailed with ${ }^{35} \mathrm{~S}$ dATP as previously described (Mulder et al., 1993). The protocol for in situ hybridization was adopted with modifications from Dagerlind et al. (1992). Fresh frozen sections $(10 \mu \mathrm{m})$ were thaw mounted onto chrome-alum-coated slides and stored overnight at $-20^{\circ} \mathrm{C}$. The slides were rapidly warmed to room temperature and the hybridization solution was applied to the sections. The hybridization buffer has previously been described (Mulder et al., 1993); the concentration of the IAPP and CGRP probes were 2.0 and $1.0 \mathrm{pmol} / \mathrm{ml}$, respectively. The IAPP probes were used separately or in a mix containing an equimolar amount of the probes. Prior to hybridization, dithiothreitol was added to the hybridization buffer at a final concentration of $0.2 \mathrm{M}$. Hybridization was carried out overnight in sealed moist chambers at $37^{\circ} \mathrm{C}$. After hybridization the coverslips were removed by immersion in $1 \times$ saline sodium citrate (SSC; $0.15 \mathrm{M} \mathrm{NaCl}, 0.015 \mathrm{M}$ sodium citrate) at room temperature. The sections were washed in $1 \times \mathrm{SSC}$ at $55^{\circ} \mathrm{C}(4 \times 15 \mathrm{~min})$ and once at room temperature $(30 \mathrm{~min})$. Finally, the sections were dehydrated and cleared in chloroform, after which they were air dried. For autoradiography, the slides were dipped in Ilford K-5 emulsion diluted 1:1 with distilled water, air dried, and kept refrigerated at $4^{\circ} \mathrm{C}$ in light-sealed boxes. After 2 and 4 weeks of exposure (CGRP and IAPP, respectively), the autoradiographs were developed in Kodak D-19 and counterstained with hematoxylin or methylene blue. For control purposes, sections were incubated in RNase A ( $45 \mu \mathrm{g} / \mathrm{m}$ ); Sigma, St. Louis, MO; $30 \mathrm{~min}$, $37^{\circ} \mathrm{C}$ ) prior to hybridization. As an additional control, a 100 -fold molar excess of unlabeled probe was added to the hybridization buffer. Autoradiographic labeling of nerve cell bodies in the control experiments was not obtained.

Immunocytochemistry. The protocols used for indirect immunofluorescence and double immunofluorescence have previously been described in detail (Mulder et al., 1993); details of the antibodies used are given in Table 1. Briefly, the sections were incubated with the primary antibody overnight at $4^{\circ} \mathrm{C}$ (48 hr for monoclonal antibodies) followed by a secondary antibody, coupled to fluorescein isothiocyanate (FITC) and with specificity for immunoglobulin $G$ of the primary antibody. In double immunofluorescence, incubation of the sections with one primary antibody was followed by an incubation overnight with a second primary antibody. Thereafter, secondary antibodies, with specificity for mouse or rabbit immunoglobulin G and coupled to either FITC or tetramethyl rhodamine isothiocyanate (TRITC), were applied to the sections. By shifting the microscope filters, the localization of two primary antibodies in a section was determined. The specificity and possible cross reactivity of the IAPP and CGRP antibodies were checked by preabsorption with human IAPP and rat $\alpha$-CGRP prior to incubation. The antigen was added to the working dilution of the antibody at a concentration of $10-100 \mu \mathrm{g} / \mathrm{ml}$. Preabsorption of the IAPP antibody with human IAPP quenched all immunostaining, whereas it was not affected by preabsorption with rat $\alpha$-CGRP. Preahsorption of the CGRP antibody with rat $\alpha$-CGRP quenched all immunostaining, whereas it was not affected by preabsorption with rat IAPP.
Morphometry. The diameters of nerve cell bodies in dorsal root ganglia labeled by the IAPP probes were determined. Using a calibrated scale bar inserted into the eyepiece of the microscope, 100 consecutive nucleated nerve cell bodies from levels $C_{1}$ to $L_{2}$ were measured in darkfield. Further, the percentage of IAPP probe-labeled nerve cell bodies (847 counted) in dorsal root ganglia was determined in two to three sections from 12 ganglia from different levels $\left(C_{1}\right.$ to $\left.L_{2}\right)$. In addition, three to four consecutive sections of the two dorsal root ganglia from levels $\mathrm{C}_{1}$ to $\mathrm{L}_{6}$ were processed for IAPP immunofluorescence. The number of IAPP-immunoreactive nerve cell bodies in each section was determined, and the frequency at each level calculated. Data on percentage of IAPP probe-labeled cells and frequency of IAPP-immunoreactive cells are given as mean \pm SEM.

Radioimmunoassay and reverse phase high-performance liquid chromatography. The RIA has previously been described in detail (Christmanson et al., 1993). Briefly, the assay is based on rabbit anti-human IAPP antiserum (Peninsula, Merseyside, UK) with labeled rat IAPP (Amersham, Solna, Sweden) as tracer; the assay detects changes between adjacent samples equivalent to $80 \mathrm{fmol} / \mathrm{gm}$ wet weight tissue. Before assay, dorsal root ganglia and specimens from spinal cord [weighing $10 \mathrm{mg}$ ( 10 pooled ganglia) and $20-50 \mathrm{mg}$, respectively] were boiled in $0.5 \mathrm{M}$ acetic acid $(10 \mathrm{ml} / \mathrm{g}$ wet weight tissue or not less than $200 \mu \mathrm{l}$ ); the extracts were assayed in duplicate dilutions equivalent to 5,15 , and $25 \mu \mathrm{l} /$ tube. Extract samples were also analyzed in a reverse phase HPLC chromatograph (LKB, Bromma, Sweden). Before chromatography, the samples were centrifuged at $2500 \mathrm{rpm}$ for $5 \mathrm{~min}$. The supernatant $(200 \mu \mathrm{l})$ was applied to a TSK gel ODS-120 T $(4.6 \times 250$ mm) column (LKB). A 30 min linear gradient of $40-53 \%$ solvent B (see below) was used at a flow rate of $0.7 \mathrm{ml} / \mathrm{min}$. Solvent $\mathrm{A}$ was $0.1 \%$ trifluoroacetic acid in water and solvent B $30 \%$ of solvent $\mathrm{A}$ in acetonitrile. The effluent was monitored at $226 \mathrm{~nm}$. Fractions $(500 \mu 1)$ were collected and dried in a Savant Speedvac SC-100 vacuum centrifuge (Techtum Lab, Umeå, Sweden) and reconstituted in $500 \mu l$ assay buffer prior to analysis for IAPP-immunoreactivity in the RIA. Standard rat IAPP (Multiple Peptide Systems, San Diego, CA) and rat $\alpha$-CGRP were used as controls.

\section{Results}

\section{In situ hybridization}

The IAPP probes labeled a population of small- to medium-sized nerve cell bodies in the dorsal root ganglia and the jugularnodose and trigeminal ganglion (Fig. 1); the CGRP probe labeled a greater number of nerve cell bodies, which were of small to large size (Fig. $1 B$ ). Both IAPP probes labeled the nerve cell bodies in the ganglia to the same extent, but the density of labeling increased when the probes were used as a mix. In the dorsal root ganglia, $24 \pm 1.4 \%$ of all nerve cell bodies were labeled by the IAPP probes. The mean diameter of nerve cell bodies was $30 \pm 0.7 \mu \mathrm{m}$; the distribution of cell diameters is 


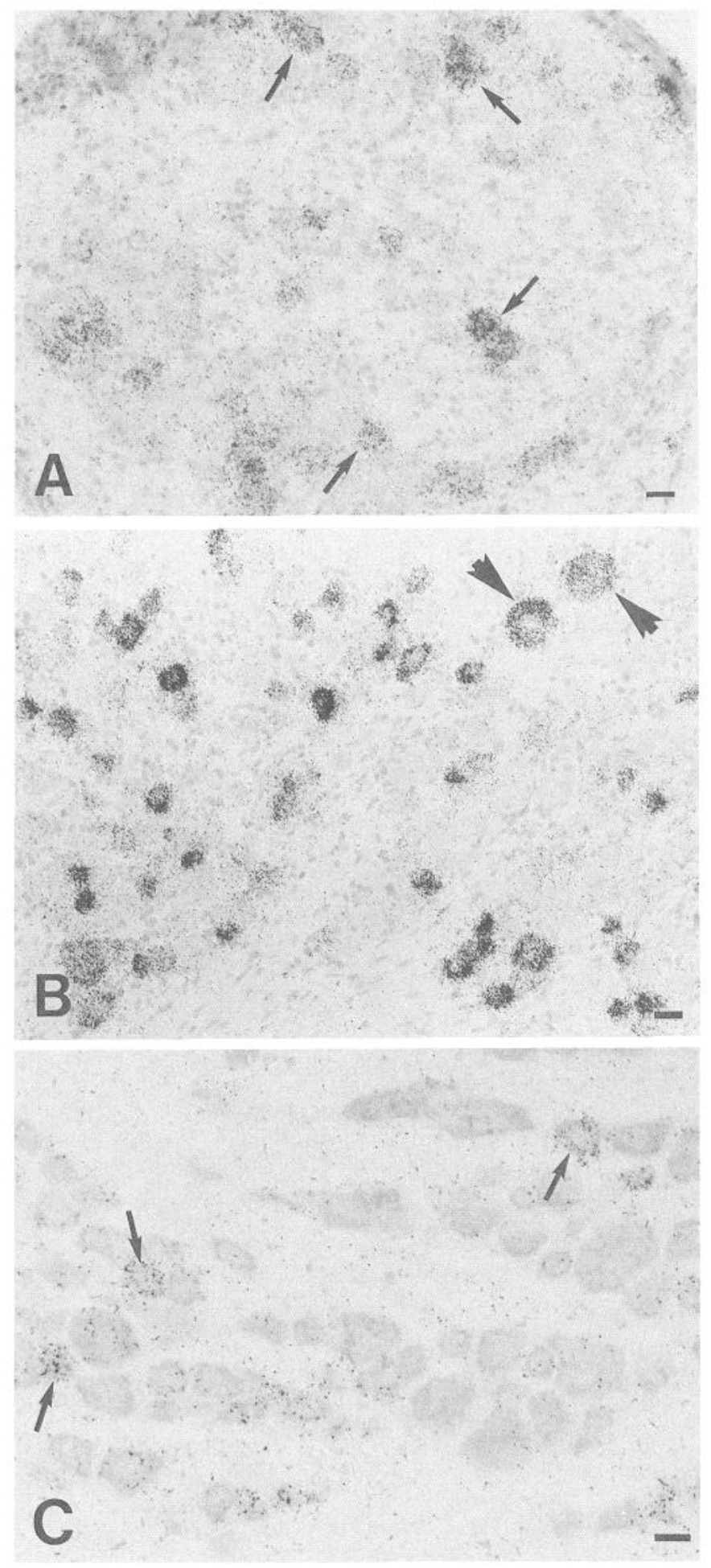

Figure 1. In situ hybridization in sensory ganglia. The IAPP probes demonstrate the presence of IAPP mRNA in a population of small- to medium-sized nerve cell bodies (arrows) in dorsal root ganglion $(A)$ and the trigeminal ganglion $(C)$. CGRP mRNA is present in a greater number of nerve cell bodies in dorsal root ganglion, including those of large size $(B$; arrowheads). Bar, $20 \mu \mathrm{m}$.

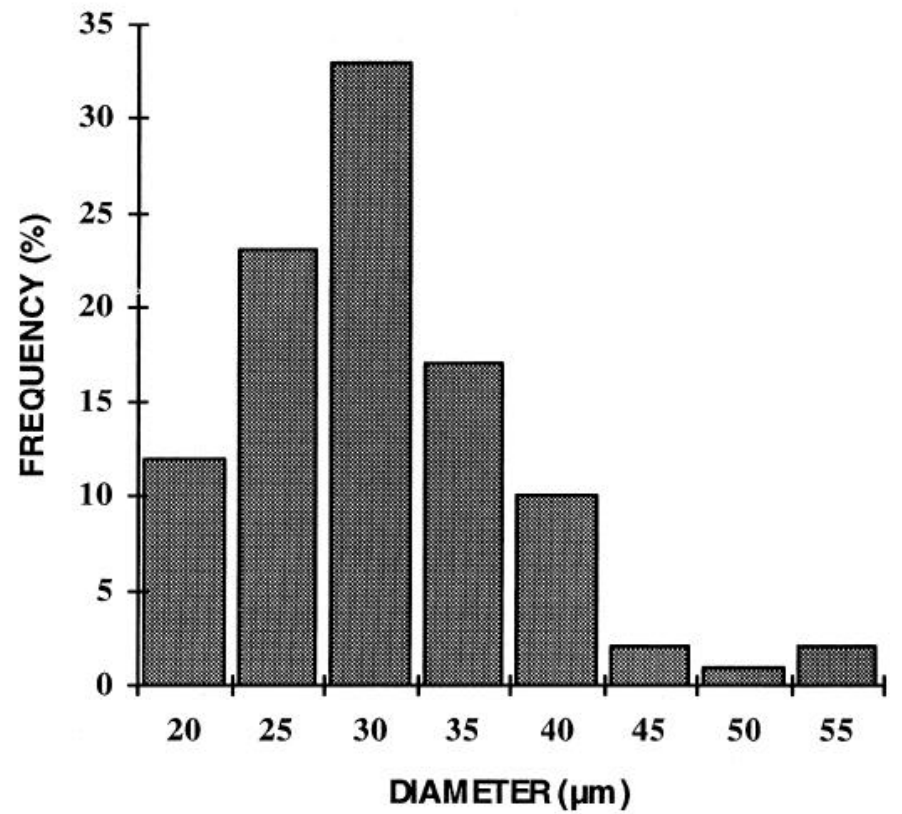

Figure 2. Diameters of nerve cell bodies in dorsal root ganglia labeled by the IAPP probes. The percentage of different diameters are given. IAPP mRNA is predominantly found in small- to medium-sized nerve cell bodies with a mean diameter of $30 \pm 0.7 \mu \mathrm{m}$.

shown in Figure 2. Hybridization with the IAPP and CGRP probes in adjacent sections from dorsal root ganglia revealed that the IAPP probes labeled a subpopulation of nerve cell bodies labeled by the CGRP probe. In the spinal cord, motoneurons were labeled by the CGRP probe but not by the IAPP probes.

\section{Immunocytochemistry}

In the adult rat, a moderate number of IAPP-immunoreactive nerve cell bodies was seen in the dorsal root ganglia and the jugular-nodose and trigeminal ganglion (Fig. $3 A, C, E$ ). The IAPP-containing nerve cell bodies, which were predominantly of small to medium size, were scattered and more numerous in the dorsal root ganglia than in the jugular-nodose and trigeminal ganglion; the frequency of IAPP-immunoreactive neurons at each level from $C_{1}$ to $L_{6}$ is shown in Figure 4, demonstrating that the IAPP-containing nerve cell bodies were most frequent at the lower thoracic levels. In the dorsal root ganglia, double immunofluorescence revealed that IAPP occurred in a subpopulation of CGRP-containing nerve cell bodies (Fig. 3A,B). Further, IAPP-like immunoreactivity was seen in a majority of the nerve cell bodies containing substance P (SP; Fig. $3 C, D$ ). In addition, a few nerve cell bodies containing IAPP also stored pituitary adenylate cyclase-activating polypeptide (PACAP). IAPP was not observed in nerve cell bodies containing somatostatin, galanin, or nitric oxide synthase. In the dorsal root ganglia, nerve fibers were seen containing IAPP/CGRP and IAPP/SP (Fig. $3 A-D$ ). In dorsal root ganglia from newborn rats (day 0), IAPP-immunoreactive nerve cell bodies were present; they were identical to the ones containing CGRP. Also, in the jugular-nodose ganglion, a small population of IAPP-immunoreactive nerve cell bodies and fibers were seen, constituting a subpopulation of those storing CGRP (Fig. $3 E, F$ ).

A dense plexus of IAPP-immunoreactive nerve fibers was found in the superficial layers of the dorsal horns in the spinal cord from both adult and newborn rats (Fig. 5A). These fibers 

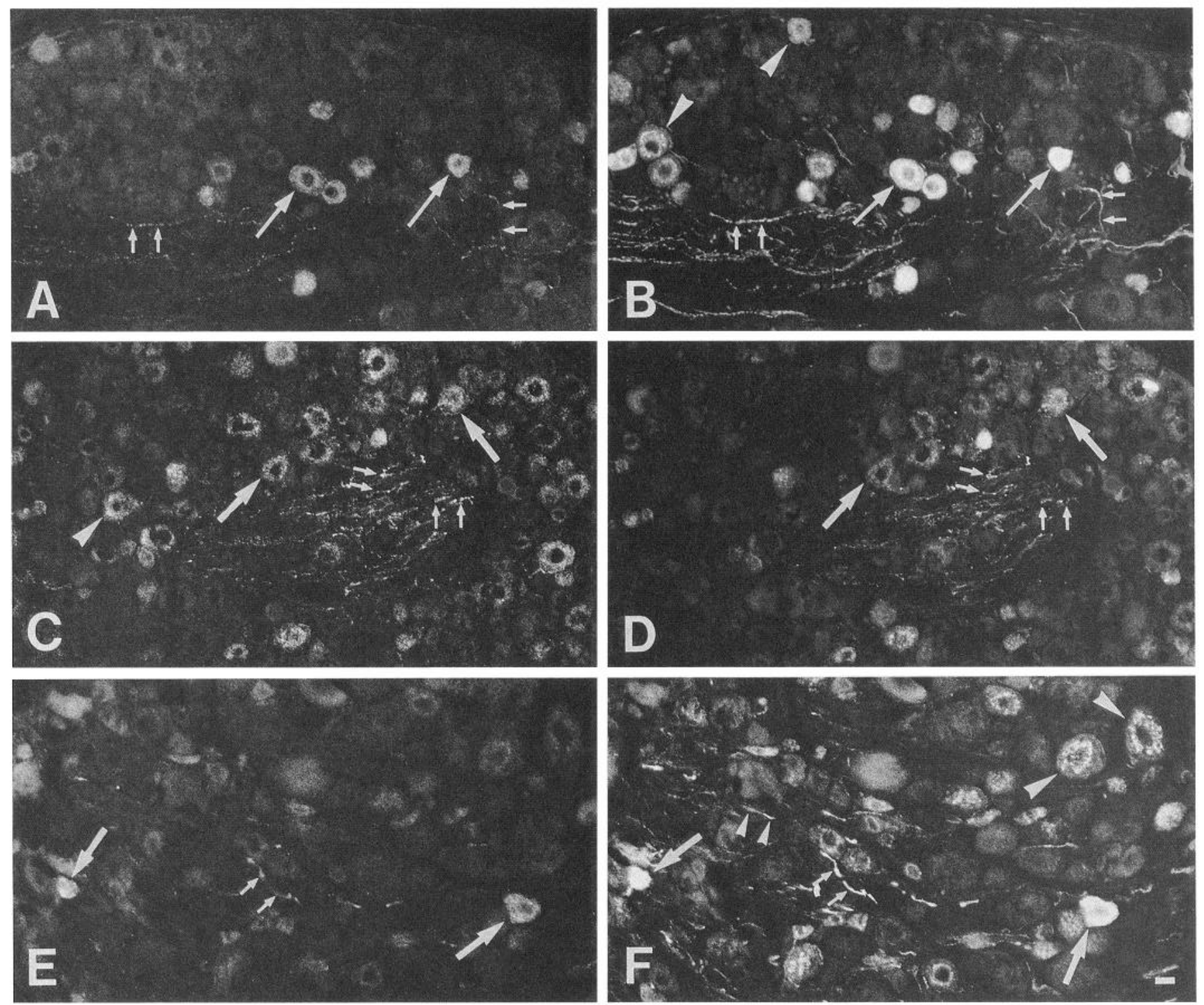

Figure 3. Double immunofluorescence. Dorsal root ganglion $(A-D)$; jugular-nodose ganglion $(E$ and $F$ ). A moderate number of IAPP-immunoreactive nerve cell bodies is seen $(A$ and $C$ ). IAPP occurs in a subpopulation of CGRP-containing neurons $(A$ and $B$; arrows), a number of CGRPcontaining neurons lacking IAPP $(B$; arrowheads). Also, note the coexistence of IAPP/CGRP in nerve fibers within the ganglia $(A$ and $B$; small arrows). IAPP occurs in a majority of the nerve cell bodies that store SP ( $C$ and $D$; arrows), although some IAPP-containing nerve cell bodies lack SP $(C$; arrowheads). In addition, IAPP coexists with SP in a population of nerve fibers $(C$ and $D$; small arrows). In the jugular-nodose ganglion, a few IAPP-immunoreactive nerve cell bodies and fibers are seen ( $E$; large and small arrows, respectively), constituting a subpopulation of those containing CGRP $(F)$; many CGRP-immunoreactive nerve cell bodies and nerve fibers lack IAPP ( $F$; large and small arrows, respectively). Bar, $20 \mu \mathrm{m}$.

contained in addition CGRP (Fig. 5B) and/or SP; the fibers containing CGRP were more numerous than the ones containing IAPP, whereas those containing SP where approximately equal in number to those containing IAPP. The posterolateral tract of Lissauer displayed dense CGRP-immunoreactivity, whereas only a sparse supply of IAPP-immunoreactive nerve fibers was seen (Fig. 5A,B). Motoneurons lacked IAPP-immunoreactivity while containing CGRP.

In the basal parts of the epithelium covering the nose and tongue (Fig. 5C), a few, delicate IAPP-containing fibers were seen. Except for a few IAPP-immunoreactive fibers in the pyloric sphincter (Fig. $5 E$ ) and in the duodenal glands of Brunner, the gastrointestinal tract was devoid of IAPP-containing nerve fibers. In contrast, immunoreactive CGRP was present in nerve fibers throughout the gastrointestinal tract (Fig. $5 F$ ) and in nerve cell bodies in the enteric ganglia. However, endocrine cells containing IAPP were encountered in the gastrointestinal tract, being most abundant in the antrum-pylorus (Fig. $5 E$ ); endocrine cells containing CGRP were not observed (Fig. $5 F$ ). In pancreatic islets, IAPP-immunoreactivity was confined to islet cells, which predominated centrally in the islets. The CGRP antibody revealed peripherally located islet cells, containing, in addition, somatostatin and IAPP, as well as scattered nerve fibers in the islets, whereas IAPP-immunoreactive nerve fibers were lacking. In the urinary bladder, a small subepithelial population of IAPPcontaining fibers was seen. In the uterus, a few IAPP-immuno- 


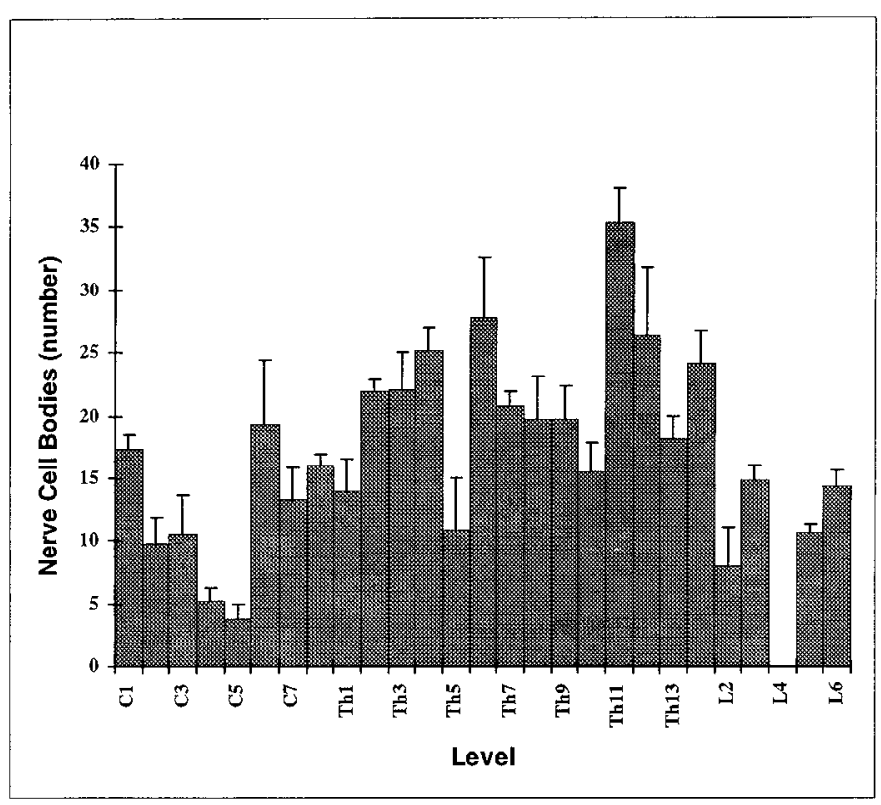

Figure 4. Frequency of IAPP-immunoreactive nerve cell bodies at different levels of dorsal root ganglia. The IAPP-immunoreactive cell bodies are present at all levels investigated (data from $\mathrm{I}_{4}$ lacking), being most abundant at the lower thoracic levels.

reactive fibers occurred among the smooth muscle bundles. All IAPP fibers seen in these tissues contained, in addition, CGRP (Fig. 5D,F); the innervation by CGRP was exceedingly more prominent with a marked perivascular occurrence, where IAPP, in contrast, was absent. IAPP was not encountered in the airways, which displayed an abundant CGRP innervation.

Immunochemistry and reverse phase high-performance liquid chromatography

In extracts from pooled dorsal root ganglia and different levels of the spinal cord, the concentration of IAPP was $3.2 \mathrm{pmol} / \mathrm{g}$ and $4.7 \pm 2.1 \mathrm{pmol} / \mathrm{g}$ wet weight tissue, respectively. Reverse phase HPLC on extracts from dorsal root ganglia and spinal cord revealed that the immunoreactivity eluted in two peaks; the first peak was smaller and eluted simultaneously with authentic rat IAPP, whereas the second corresponded to authentic rat $\alpha$-CGRP (Fig. 6). The elution profiles were identical in the extracts from dorsal root ganglia and spinal cord, and no other immunoreactive peaks appeared.

\section{Discussion}

In this study, we present evidence that IAPP is expressed in sensory neurons. Thus, besides being an islet hormone candidate, IAPP is also a putative sensory neuropeptide. IAPP was expressed in a population of small- to medium-sized neurons in the trigeminal, jugular-nodose, and dorsal root ganglia. The sensory nature of IAPP was confirmed by the finding of IAPPimmunoreactive neurons forming a dense plexus in the superficial layers of the dorsal horns in the spinal cord, in a manner similar to that of CGRP and other sensory neuropeptides (Sundler et al., 1985). Also, in peripheral tissues with a prominent sensory innervation, a sparse supply of IAPP-containing fibers was encountered. The level of IAPP mRNA in nerve cell bodies conceivably was low, since the exposure time for the IAPP probes and probe concentrations were twice that of the CGRP probe, while still yielding a weaker labeling of neurons. Fur- thermore, the concentration of IAPP in extracts from dorsal root ganglia and spinal cord was low (3-5 pmol/g), as compared to that previously reported for CGRP (approximately $500 \mathrm{pmol} / \mathrm{g}$; Mulderry et al., 1988).

In the ganglia and tissues examined, in which IAPP occurred in neuronal elements, expression of IAPP was seen in a subpopulation of CGRP-containing neurons; IAPP mRNA was present in $24 \%$ of the neurons in dorsal root ganglia, whereas CGRP mRNA occurs in $37-46 \%$ of the neurons in dorsal root ganglia (Noguchi et al., 1993; Mulder et al., 1994b). In certain tissues heavily innervated by CGRP, such as the gastrointestinal tract and airways, IAPP occurred sparsely or was lacking. However, as previously demonstrated (Mulder et al., 1994a), IAPP occurred in gastrointestinal endocrine cells, whereas CGRP was absent from such cells. The colocalization of IAPP and CGRP was not entirely surprising, since the two peptides have probably evolved due to a duplication of an ancestral gene (Nishi et al., 1989). It is not inconceivable that the two genes through evolution have retained some common regulatory elements that determine the site of their expression; in this case, a population of sensory neurons. In neuronal tissues, it is not uncommon that structurally related peptides with similar biological effects are colocalized. Thus, SP and neurokinin A are coexpressed in sensory neurons, the peptides deriving from the same gene and having similar biological effects (Sundler et al., 1985). In addition, IAPP was colocalized with SP and PACAP, which are both known to coexist with CGRP in sensory neurons (Sundler et al., 1985; Moller et al., 1993).

A major concern in our study was to establish the molecular and chemical identity of IAPP mRNA and IAPP in sensory neurons, since the structurally related neuropeptide CGRP (Westermark et al., 1986; Cooper et al., 1987) is ubiquitously expressed in the sensory nervous system (Sundler et al., 1985; Ishida-Yamamoto and Tohyama, 1989). The IAPP probes used for in situ hybridization lacked sequence homology with CGRP mRNA. Further, the labeling of the two IAPP probes was identical in the ganglia, and the control experiments were negative. Collectively, this ensured a high degree of specificity in the hybridization experiments. The immunostaining of nerve cell bodies or fibers was not affected by preabsorption of the monoclonal IAPP antibody with CGRP, making a crossreaction with CGRP unlikely. Moreover, IAPP-like immunoreactivity was absent from several sites displaying CGRP-like immunoreactivity and, even in the same section, CGRP-containing neurons were seen to lack IAPP. These observations support the presumption that the monoclonal IAPP antibody does not recognize CGRP. Reverse phase HPLC on extracts from dorsal root ganglia and spinal cord yielded one small peak coeluting with authentic rat IAPP and one larger peak coeluting with rat $\alpha$-CGRP. This is explained by the fact that the polyclonal antibody used in the RIA crossreacts slightly with CGRP (approximately $0.4 \%$; unpublished result), which is present in these tissues at a much higher concentration than IAPP (see above). Although the exact concentration of IAPP in the dorsal root ganglia and spinal cord remains unresolved, conceivably being low (in the range of $1-2 \mathrm{pmol} / \mathrm{g}$ ), the chromatographic data are in agreement with the hybridization and immunocytochemical findings and, thus, further support that IAPP is expressed in the dorsal root ganglia and spinal cord.

At this point, one can only speculate on the role of IAPP in sensory neurons. IAPP was expressed in part in sensory neurons of small size; such neurons give rise to C-type unmyelinated fibers, which are known to convey nociceptive transmission to 

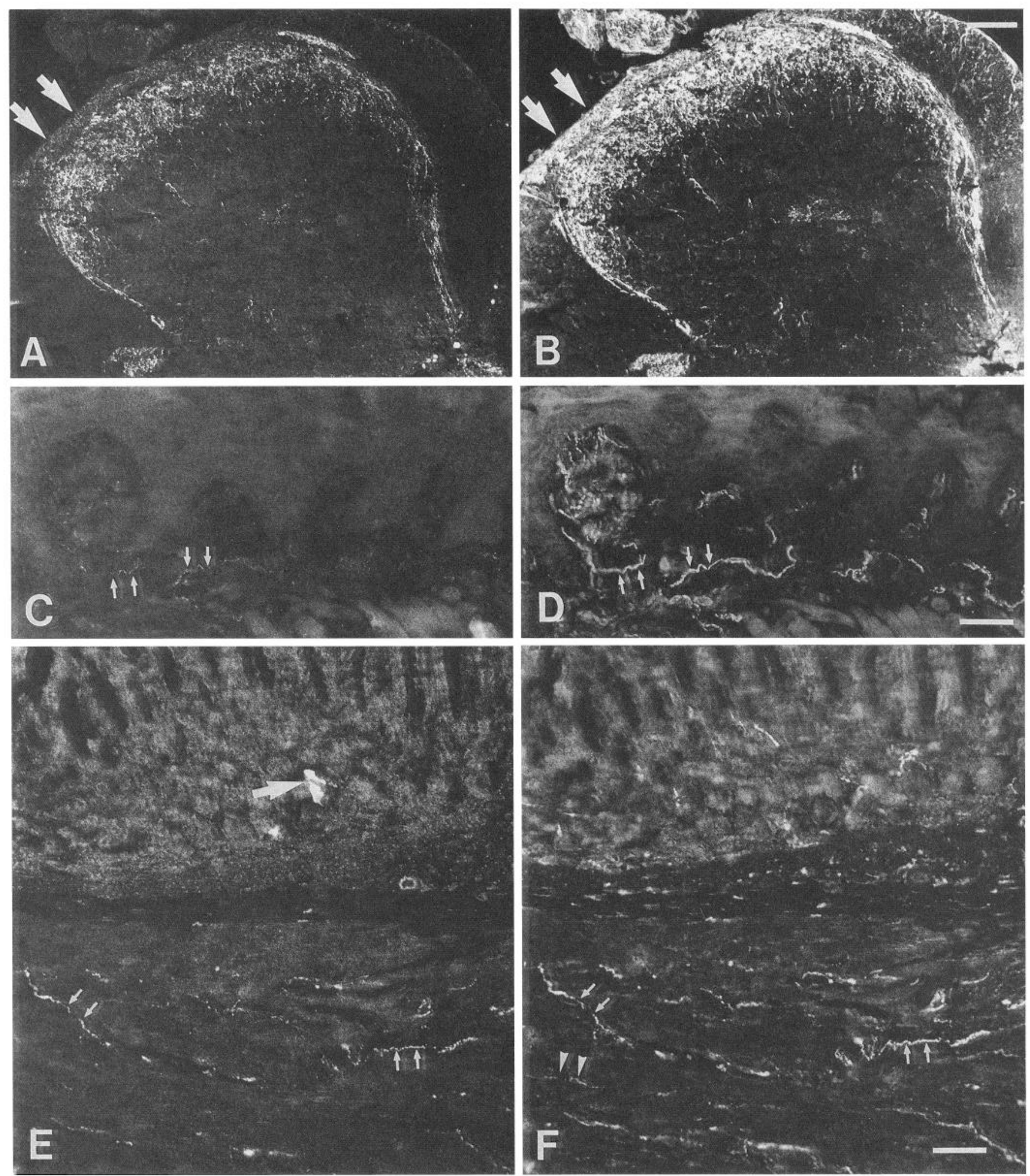

Figure 5. Double immunofluorescence. In the spinal cord $(A$ and $B)$, IAPP-immunoreactive neurons form a plexus in the superficial layers of the dorsal horns $(A)$. These fibers have a similar distribution to those containing CGRP $(B)$, but are fewer and less intensely stained. Note the scarcity of immunoreactive IAPP in Lissauer's tract $(A ;$ arrow), which displays a dense innervation by CGRP $(B ;$ arrow). In the tongue $(C$ and $D)$, a sparse supply of IAPP-immunoreactive nerve fibers runs beneath the epithelium and encircles a papilla ( $C$; arrows); these fibers constitute a subpopulation of CGRP-containing nerve fibers $(D$; arrows). The pyloric musculature displays a few delicate IAPP-containing nerve fibers $(E$; small arrows), constituting a subpopulation of CGRP-containing nerve fibers $(F$; small arrows). Note that some CGRP-fibers $(F$; arrowheads) lack IAPP. IAPPimmunoreactive endocrine cells are present in the mucosa ( $E$; large arrow); these cells are devoid of CGRP-immunoreactivity. Bars: $A$ and $B, 100$ $\mu \mathrm{m} ; C$ and $D, 50 \mu \mathrm{m} ; E$ and $F, 50 \mu \mathrm{m}$. 


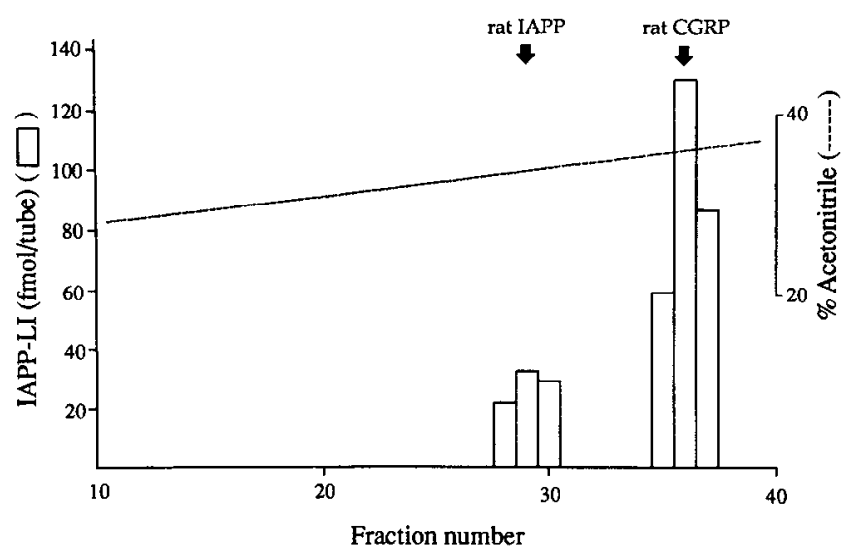

Figure 6. Reverse phase HPLC elution profile of IAPP-like immunoreactive material in extracts from rat spinal cord. The elution positions of authentic rat IAPP and rat $\alpha$-CGRP and the elution gradient are indicated. Two peaks corresponding to rat IAPP and rat $\alpha$-CGRP, respectively, are seen, indicating that the polyclonal antibody used in the RIA recognizes both peptides, the avidity for rat $\alpha$-CGRP being several orders of magnitude lower. Due to the crossreactivity, the concentration of IAPP remains unresolved but is presumably much lower than that of CGRP (approximately 1-2 $\mathrm{pmol} / \mathrm{gm}$ ).

the spinal cord and the brainstem. Thus, IAPP may, under certain conditions, participate in such events. Furthermore, IAPP has been shown to have vasodilatory effects, although being less potent than CGRP (Brain et al., 1990). Hence, a role for IAPP in edema formation in neurogenic inflammation cannot be ruled out. The effects of IAPP could be mediated by receptors also utilized by CGRP. Indeed, it has previously been demonstrated that IAPP can interact with CGRP receptors (Morishita et al., 1990). Thus, it is possible that binding of IAPP and CGRP to a group of receptors, although with differing affinity (Bhogal et al., 1992), could allow for graded responses at the target tissue innervated, depending on the relative amounts of IAPP and CGRP released. A putative IAPP receptor binding IAPP with a 10-150-fold higher affinity than CGRP has been reported (Bhogal et al., 1992); these binding sites are localized in several peripheral tissues, such as the lung, fundus, spleen, and liver, as well as in the brainstem and some areas of the brain (Bhogal et al., 1992). Recently, a high affinity IAPP binding site in the brain has been characterized (Beaumont et al., 1993; Sexton et al., 1994; van Rossum et al., 1994), possibly being identical to the C3 receptor previously described (Sexton et al., 1988). A common feature of these binding sites is that other peptides than IAPP interact with high potency at these sites. Adrenomedullin, an adrenal 50 amino acid polypeptide related to IAPP/CGRP (Kitamura et al., 1993; Sakata et al., 1993), displaces IAPP from its binding sites in the lung (Owji et al., 1995), and salmon calcitonin has a similar affinity for the IAPP-binding sites in the brain (Beaumont et al., 1993). Binding sites for IAPP in the tissues, in which we report the presence of IAPP in nerve fibers, remain to be shown. The restricted expression of IAPP as compared to that of CGRP could suggest that also the role of IAPP may deviate from that of CGRP. Whether the expression of IAPP in sensory neurons is altered under pathological conditions remains to be established.

\section{References}

Amara SG, Evans RM, Rosenfeld MG (1984) Calcitonin/calcitonin gene-related peptide transcription unit: tissue-specific expression in- volves selective use of alternative polyadenylation sites. Mol Cell Biol 4:2151-2160.

Beaumont K, Kenney MA, Young AA, Rink TJ (1993) High affinity amylin binding sites in rat brain. Mol Pharmacol 44:493-497.

Bhogal R, Smith DM, Bloom SR (1992) Investigation and characterization of binding sites for islet amyloid polypeptide in rat membranes. Endocrinology 130:906-913.

Brain SD, Wimalawansa S, MacIntyre I, Williams TJ (1990) The demonstration of vasodilator activity of pancreatic amylin amide in the rabbit. Am J Pathol 136:487-490.

Christmanson L, Betsholtz C, Leckström A, Engström U, Cortie C, Johnson KH, Adrian TE, Westermark P (1993) Islet amyloid polypeptide in the rabbit and European hare: studies on its relationship to amyloidogenesis. Diabetologia 36:183-188.

Cooper GJ, Willis AC, Clark A, Turner RC, Sim RB, Reid KB (1987) Purification and characterization of a peptide from amyloid-rich pancreases of type 2 diabetic patients. Proc Natl Acad Sci USA 84:86288632.

Dagerlind $\AA$, Friberg K, Bean AJ, Hökfelt T (1992) Sensitive mRNA detection using unfixed tissue: combined radioactive and non-radioactive in situ hybridization histochemistry. Histochemistry 98:39-49.

Fan L, Westermark G, Chan SJ, Steiner DF (1994) Altered gene structure and tissue expression of islet amyloid polypeptide in the chicken. Mol Endocrinol 8:713-721.

Ferrier GJ, Pierson AM, Jones PM, Bloom SR, Girgis SI, Legon S (1989) Expression of the rat amylin (IAPP/DAP) gente. J Mol Endocrinol 3:R1-R4.

Frontoni S, Choi SB, Banduch D, Rossetti L (1991) In vivo insulin resistance induced by amylin primarily through inhibition of insulinstimulated glycogen synthesis in skeletal muscle. Diabetes 40:568573.

Fürnsinn C, Leuvenink H, Roden M, Nowotny P, Schneider B, Rohac M, Pieber T, Clodi M, Waldhäusl W (1994) Islet amyloid polypeptide inhibits insulin secretion in conscious rats. Am J Physiol 267: E300-E305.

Höppener JVM, Steenbergh PH, Zandberg J, Bakker E, Pearson PL, Geurts van Kessel AIIM, Jansz IIS, Lips CJM (1984) Localization of the polymorphic human calcitonin gene on chromosome 11 . Hum Genet 66:309-312

Ishida-Yamamoto A, Tohyama M (1989) Calcitonin gene-related peptide in the nervous system. Prog Neurobiol 33:335-386.

Johnson KH, O'Brien TD, Hayden DW, Jordan K, Ghobrial HK, Mahoney WC, Westermark P (1988) Immunolocalization of islet amyloid polypeptide (IAPP) in pancreatic beta cells by means of peroxidase-antiperoxidase (PAP) and protein A-gold techniques. Am J Pathol 130:1-8.

Kitamura K, Kangawa K, Kawamoto M, Ichiki Y, Nakamura S, Matsuo H, Eto T (1993) Adrenomedullin: a novel hypotensive peptide isolated from human pheochromocytoma. Biochem Biophys Res Commun 192:553 -560.

Leffert JD, Newgard CB, Okamoto H, Milburn JL, Luskey KL (1989) Rat amylin: cloning and tissue-specific expression in pancreatic islets. Proc Natl Acad Sci USA 86:3127-3130.

Leighton B, Cooper GJ (1988) Pancreatic amylin and calcitonin generelated peptide cause resistance to insulin in skeletal muscle in vitro. Nature 335:632-635.

Lukinius A, Wilander E, Westermark GT, Engström U, Westermark P (1989) Co-localization of islet amyloid polypeptide and insulin in the B cell secretory granules of the human pancreatic islets. Diabetologia 32:240-244.

Moller K, Zhang Y-Z, Håkanson R, Luts A, Sjölund B, Uddman R, Sundler F (1993) Pituitary adenylate cyclase activating peptide is a sensory neuropeptide: immunocytochemical and immunochemical evidence. Neuroscience 57:725-732.

Morishita T, Yamaguchi A, Fujita T, Chiba T (1990) Activation of adenylate cyclase by islet amyloid polypeptide with $\mathrm{COOH}$-terminal amide via calcitonin gene-related peptide receptors on rat liver plasma membranes. Diabetes 39:875-877.

Mulder H, Lindh AC, Ekblad E, Westermark P, Sundler F (1994a) Islet amyloid polypeptide is expressed in endocrine cells of the gastric mucosa in the rat and mouse. Gastroenterology 107:712-719.

Mulder H, Uddman R, Moller K, Ekblad E, Alumets J, Sundler F (1994b) Pituitary adcnylate cyclase activating peptide (PACAP) expression in sensory neurons. Neuroscience 63:307-312.

Mulder H, Lindh A-C, Sundler F (1993) Islet amyloid polypeptide gene 
expression in the endocrine pancreas of the rat: a combined in situ hybridization and immunocytochemical study. Cell Tissue Res 274: $467-474$.

Mulderry PK, Ghatei MA, Spokes RA, Jones PM, Pierson AM, Hamid QA, Kanse S, Amara SG, Burrin JM, Legon S, Polak JM, Bloom SR (1988) Differential expression of alpha-CGRP and beta-CGRP by primary sensory neurons and enteric autonomic neurons of the rat. Neuroscience 25:195-205

Nicholl CG, Bhatavdekar JM, Mak J, Girgis SI, Legon S (1992) Extrapancreatic expression of the rat islet amyloid polypeptide (amylin) gene. J Mol Endocrinol 9:157-163.

Noguchi K, De Leon M, Nahin RL, Senba E, Ruda MA (1993) Quantification of axotomy-induced alteration of neuropeptide mRNAs in dorsal root ganglion neurons with special reference to neuropeptide $Y$ mRNA and the effects of neonatal capsaicin treatment. J Neurosci Res 35:54-66.

Owji AA, Smith DA, Coppock HA, Morgan DGA, Bhogal R, Ghatei MA, Bloom SR (1995) An abundant and specific binding site for the novel vasodilator adrenomedullin in the rat Endocrinology 136: $2127-2134$

Sakata J, Shimokubo T, Kitamura K, Nakamura S, Kangawa K, Matsuo $\mathrm{H}$, Eto $\mathrm{T}$ (1993) Molecular cloning and biological activities of rat adrenomedullin, a hypotensive peptide. Biochem Biophys Res Commun 195:921-927.

Sexton PM, McKenzie JS, Mendelsohn FAO (1988) Evidence for a new subclass of calcitonin/calcitonin gene-related peptidc binding sitc in rat brain. Neurochem Int 12:323-335.

Sexton PM, Paxinos G, Kenney MA, Wookey PJ, Beaumont K (1994) In vitro autoradiographic localization of anylin binding sites in rat brain. Neuroscience 62:553-567.

Sundler F, Brodin E, Ekblad E, Håkanson R, Uddman R (1985) Sensory nerve fibers: distribution of substance $P$, neurokinin $A$ and calcitonin gene-related peptide. In: Tachykinin antagonists (Håkanson $R$, Sundler F, eds), pp 3-14. Amsterdam: Elsevier.

van Rossum D, Menard DP, Fournier A, St-Pierre S, Quirion R (1994) Autoradiographic distribution and receptor binding profile of [I125]Bolton Hunter-rat amylin binding sites in the rat brain. J Pharmacol Exp Ther 270:779-787.

Wang ZL, Bennet WM, Ghatei MA, Byfield PG, Smith DM, Bloom SR (1993) Influence of islet amyloid polypeptide and the 8-37 fragment of islet amyloid polypeptide on insulin release from perifused rat islets. Diabetes 42:330-335.

Westermark P, Wernstedt C, Wilander E, Sletten K (1986) A novel peptide in the calcitonin gene related peptide family as an amyloid fibril protein in the endocrine pancreas. Biochem Biophys Res Commun 140:827-831. 